\title{
LUNG VENTILATION PATTTERNS DETERMINED BY ANALYSIS \\ OF NITROGEN ELIMINATION RATES; USE OF THE MASS SPECTROMETER AS A CONTINUOUS GAS ANALYZER ${ }^{1}$
}

\author{
By JAMES S. ROBERTSON,² WILLIAM E. SIRI, AND HARDIN B. JONES \\ (From the Division of Medical Physics, University of California, Berkeley, California)
}

(Submitted for publication September 1, 1949; accepted, January 16, 1950)

A quantitative measure of the effectiveness of lung ventilation and the significance of unequal mixing of the gases in the lung is of interest in many problems such as the measurement of lung volume and in studies of such processes as tissue denitrogenation which involve transport of gases through the lung.

The present study involves the determination of the turnover rates attained in the lung from measurements of the rate at which nitrogen is washed out of the lungs while the subject is breathing pure oxygen. It has been recognized (1) that this rate depends upon the distribution of the tidal breath to the deeper pulmonary structures and that it offers a means of measuring the ventilatory process. Use of the method has, however, led to a number of different expressions for the effectiveness of ventilation none of which we believe is definitive of the process.

Because the function of lung ventilation is to maintain physiological partial pressures of oxygen and of carbon dioxide in the alveoli it seems to us that the measure of the effectiveness of ventilation should be reciprocally related to the average time that a molecule remains in those spaces. The replacement rate or turnover rate, defined as the ratio of the number of new molecules which enter a space in unit time to the number present at the end of expiration is such a measure.

Without attempting here to survey the extensive literature upon this subject we shall mention a few papers which bear most directly upon the interpretation of the present results.

Cournand and his associates $(1,2)$ in testing the adequacy of the assumption of even pulmonary

1 This work was supported in part by the Life Insurance Medical Research Fund and in part by the Army Air Force.

2 Present address: Medical Department, Brookhaven National Laboratory, Upton, Long Island, New York. mixing found evidence of unequal mixing in emphysematous subjects and to some extent in normal ones. They develop the "pulmonary emptying rate" as a criterion for the effectiveness of lung ventilation. This is based upon the concentration of nitrogen remaining in the alveoli after seven minutes of oxygen breathing. In effect this establishes two points on the curve representing the concentration of nitrogen as a function of time, the initial point and the seven-minute one. This function is not, however, defined by these two points unless it is a simple function having only two constants, such as a single-termed exponential. Non-uniform mixing is not consistent with any simple function; with different degrees of mixing two curves differing appreciably can both pass through these two points but be quite different at other times. In a later paper Darling, Cournand, and Richards (3) compare the concentration of nitrogen remaining after a period of oxygen breathing to the concentration they predict would have been obtained had mixing been perfect and they express the effects of unequal mixing as the percentage failure of ventilation.

Meneely and Kaltreider (4) consider the effects of mixing upon the time required to attain equilibrium in a closed circuit and publish curves showing how equilibrium is approached. The concept involved is similar to the "pulmonary emptying rate" of Cournand and his colleagues (2). Their published curves are susceptible to an analysis similar to that to be discussed in the present paper.

Another method for expressing the effects of non-uniform ventilation has been to estimate the volume of the dead space. Birath (5) points out that it is impossible to distinguish between the effects of unequal mixing and those of increased dead space in the analysis of gas elimination curves. He expresses all such effects as dead space volume and presents a large series of de- 
terminations, with emphasis on the changes produced by lung surgery.

A similar theory is inherent in the work of Bateman (6) in which the consequences of imperfect mixing are expressed in terms of the volumes of the functional residual air and of the dead space. Bateman and associates (7) also describe a method of serial sampling for extending the open-circuit methods of measuring lung volume to a study of lung clearance rates.

Boothby, Lundin, and Helmholz (8) measure the total nitrogen eliminated while the subject is rebreathing in a closed circuit and plot the log of the accumulated nitrogen against the log of time. They use the knee which results in the curve of such a plot as the index for the end of the lung washing out process and the beginning of the tissue denitrogenation process. Such a knee would appear in the curve if no nitrogen whatsoever were coming from the tissues so this does not seem to be a valid measure of lung ventilation.

Forssander and White (9) consider the problem of the mixing of the alveolar air with the dead space air.

Riley and Cournand (10) take the effects of unequal mixing into consideration in their presentation of an "ideal" alveolar air. This is the one value for the $\mathrm{pCO}_{2}$ and the $\mathrm{pO}_{2}$ which could exist homogenously throughout all parts of the lung and still be compatible with the quantitative aspects of gas exchange. A similar concept expressed as a mean alveolar gas composition is presented by Rahn $(11,12)$.

A few papers bearing upon the question of the role of diffusion in the lung will be mentioned later.

\section{APPARATUS AND TECHNIC}

Figure 1 schematically represents the apparatus used in these experiments. $99.5 \%$ pure oxygen is supplied the subject through a reducing valve and a demand valve which is so designed that oxygen flows only when the subject inhales. Flutter valves control the direction of flow so that only tank oxygen is inhaled. The expired air is mixed in a $400 \mathrm{cc}$. baffle. The bulk of the expired air is collected in a 100 liter spirometer. The sample to be measured is bled off as indicated in Figure 1 and led past the needle valve of the mass spectrometer at about $150 \mathrm{cc} . / \mathrm{min}$. The needle valve further controls the flow into the ionization chamber of the instrument. The mass spectrometer used is the one previously described by Siri (13). It provides an instantaneous, continuous analysis of the gases admitted into its ionization chamber. A recording milliammeter is used which requires a minimum of about one second for the pen to swing over its full scale, so changes with a half time faster than five seconds are not accurately recorded. The instrument provides an accuracy of $\pm 2 \%$ at high nitrogen concentrations and $\pm 10 \%$ at nitrogen concentrations of the order of $\frac{1}{2}$ of $1 \%$.

Most of the experiments were performed in the morning with the subjects in a standardized non-basal resting condition and in the sitting position. Masks covering both the nose and mouth were used. In general these were held in

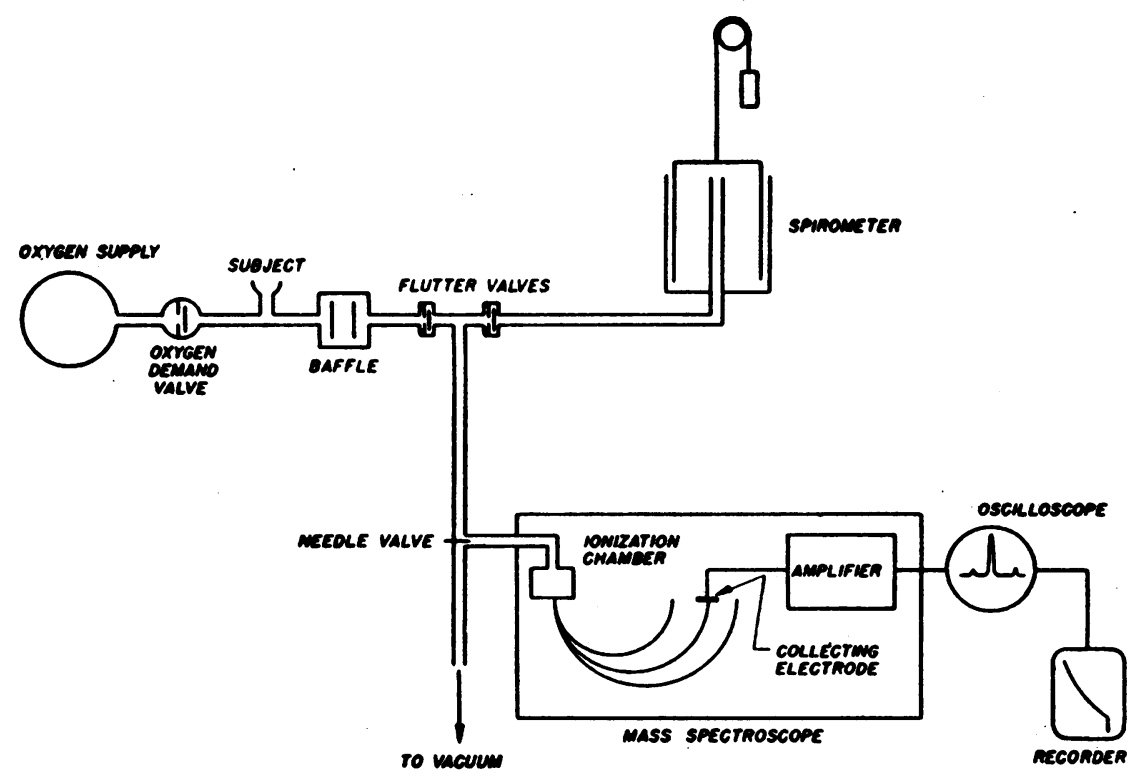

Fig. 1. Schematic Representation of Apparatus Used in Denitrogenation STUdies 
place only by head straps, but when there was doubt that this would prevent mask leaks, the mask was secured to the subject's face with rubber cement. A valve near the mask permits the subject to continue breathing atmospheric air during adjustment of the mask and the last minute checks on the instrument. The subject starts to breathe oxygen at the beginning of an inhalation and a continuous record of the concentration of nitrogen in the exhaled air is obtained from this instant until the end of the experiment ten minutes later.

The normal subjects used were all university employees or other persons known to be in good health. A series of subjects afflicted with polycythemia vera was obtained from Dr. John H. Lawrence's clinic. Subjects with established lung pathology were obtained from the University of California Hospital and the Highland Alameda Hospital through the courtesy and cooperation of Dr. Rolfe Salin and Dr. Hallam Cope. None of the subjects except the polycythemic ones had an elevated red count.

\section{THEORY $^{3}$}

If pure oxygen enters a given space of the lung during inspiration and is completely mixed with the initial contents of the space before expiration, the nitrogen in the space is diluted by a factor of $\left(\frac{V}{V+T}\right)$ with each respiration, where $V$ is the volume of the space at the end of expiration and $\mathrm{V}+\mathrm{T}$ the volume at the end of inspiration and where the addition of nitrogen by diffusion from the tissues is neglected for the moment. The quantity remaining at the end of any expiration is then given by the equation:

$$
Q=Q_{0}(V / V+T)^{n t}
$$

where $Q$ is the quantity in the space at the end of any number of respirations, $n t ; Q_{0}$ is the amount originally present; $\mathbf{n}$ is the respiratory rate; and $\mathrm{nt}$ has integer values. If $\mathbf{n}$ is allowed to increase without limit while $T$ becomes vanishingly small in such a manner that $n T$, the minute volume, remains constant, this function approaches

$$
\mathrm{Q}=\mathrm{Q}_{0} \mathrm{e}^{-\mathrm{kt}}
$$

as a limit, where $k=n T / V$ and by definition is the turnover rate. For present purposes $Q$ is sufficiently accurately represented by Equation (2). The rate of change of $Q, d Q / d t$, is the rate at which nitrogen appears in the expired air:

$$
\mathrm{dQ} / \mathrm{dt}=-\mathrm{k}_{0} \mathrm{e}^{-k t}
$$

Using $R$ to denote this rate and defining $R_{0}=-k Q_{0}$ this is:

$$
R=R_{0} e^{-k t}
$$

If the lung consists of several spaces which are ventilated independently of each other, or by analogy with electrical circuit terminology are regarded as being in parallel, the combined nitrogen elimination rate is simply the sum of a series of such terms, with one term for each space or group

3 A more detailed presentation of the theory is given in: Robertson, J. S., Thesis. Lung ventilation patterns and their physiological significance, University of California, 1949.

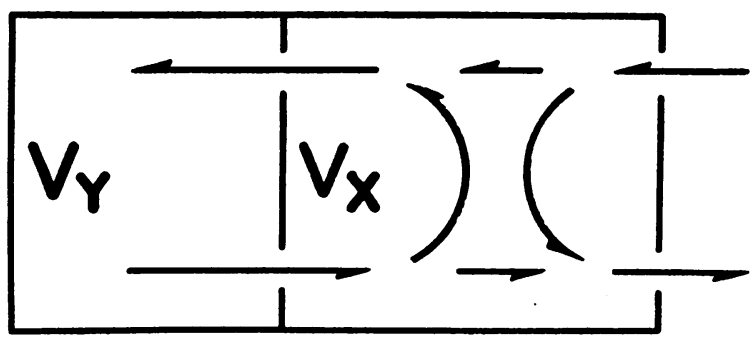

Fig. 2. Schematic Representation of two Compartments Ventilated in Series

Some air recirculates, so the number of molecules entering and leaving the deep space is greater than the number being replaced in unit time. A mathematical analysis of this situation is given in the text.

of spaces with the same turnover rate:

$$
R=R_{1_{0}} e^{-k_{1} t}+R_{2_{0}} e^{-k_{2} t}+\cdots
$$

In general, however, the diluting volume for the deeper spaces is not pure oxygen, but a mixture determined by the events in the more proximal spaces. In all cases the rate of change of nitrogen in a space is the difference between the rate at which it enters and the rate at which it leaves. For two spaces with $\mathrm{Y}$ deep to $\mathrm{X}$, as represented schematically in Figure 2, the relationships are expressed by the equations:

$$
\left\{\begin{array}{l}
\frac{d V_{Y} Y}{d t}=k_{2} V_{Y} X-k_{2} V_{Y} Y \\
\frac{d V_{X} X}{d t}=-\left[k_{2} V_{Y} X-k_{2} V_{Y} Y\right]-k_{1} V_{X} X
\end{array}\right.
$$

where

$X$ is the concentration in the proximal space

$Y$ is the concentration in the deep space

$\mathrm{V}_{\mathbf{X}} \mathrm{X}$ is the quantity in the proximal space

$\mathrm{VYY}_{\mathbf{Y}} \mathrm{Y}$ is the quantity in the deep space

$k_{1} V_{X X} X$ is the rate nitrogen is leaving the proximal space in the expired air

$\mathbf{k}_{\mathbf{2}} \mathrm{V}_{\mathbf{Y}} \mathrm{X}$ is the rate nitrogen is passing from the proximal space to the deeper one

$\mathrm{k}_{2} \mathrm{~V}_{\mathrm{Y}} \mathrm{Y}$ is the rate nitrogen is passing from the deep space to the proximal one.

It is assumed that the amount entering the proximal space in the inspired air is zero.

Dividing Equation (5) by $V_{Y}$ and Equation (6) by $V_{X}$ the equations simplify to

where

$$
\left\{\begin{array}{l}
d Y / d t=k_{2} X-k_{2} Y \\
d X / d t=-\left(k_{1}+k_{3}\right) X-k_{3} Y
\end{array}\right.
$$

$$
\mathbf{k}_{\mathbf{8}}=\mathbf{k}_{\mathbf{2}}\left(\mathrm{V}_{\mathbf{Y}} / \mathrm{V}_{\mathbf{X}}\right) \text {. }
$$

The procedure for solving this system of ordinary linear equations is available in any elementary text book of differential equations. The explicit solutions for $\mathrm{X}$ and $\mathrm{Y}$ are:

$$
\begin{aligned}
& X=C_{1} e^{m_{1} t}+C_{2} e^{m_{2} t} \\
& Y=C_{2} e^{m_{1} t}+C_{1} e^{m_{2} t}
\end{aligned}
$$


in which the constants $C$ and the exponents $m$ are related to the turnover rates as follows:

$$
\begin{aligned}
\mathrm{m}_{1-} & =\frac{-\left(\mathrm{k}_{1}+\mathrm{k}_{2}+\mathrm{k}_{2}\right) \pm \sqrt{\left(\mathrm{k}_{1}+\mathrm{k}_{2}+\mathrm{k}_{3}\right)^{2}-4 \mathrm{k}_{1} \mathrm{k}_{2}}}{2} \\
\mathrm{C}_{1} & =\frac{\mathrm{m}_{2}+\mathrm{k}_{1}}{\mathrm{~m}_{2}-\mathrm{m}_{1}} \mathrm{X}_{0} \\
\mathrm{C}_{2} & =\frac{\mathrm{m}_{1}+\mathrm{k}_{1}}{\mathrm{~m}_{1}-\mathrm{m}_{2}} \mathrm{X}_{0} \\
\mathrm{C}_{8} & =\frac{\mathrm{m}_{2}}{\mathrm{~m}_{2}-\mathrm{m}_{1}} \mathrm{Y}_{0} \\
\mathrm{C}_{4} & =\frac{\mathrm{m}_{1}}{\mathrm{~m}_{1}-\mathrm{m}_{2}} \mathrm{Y}_{0}
\end{aligned}
$$

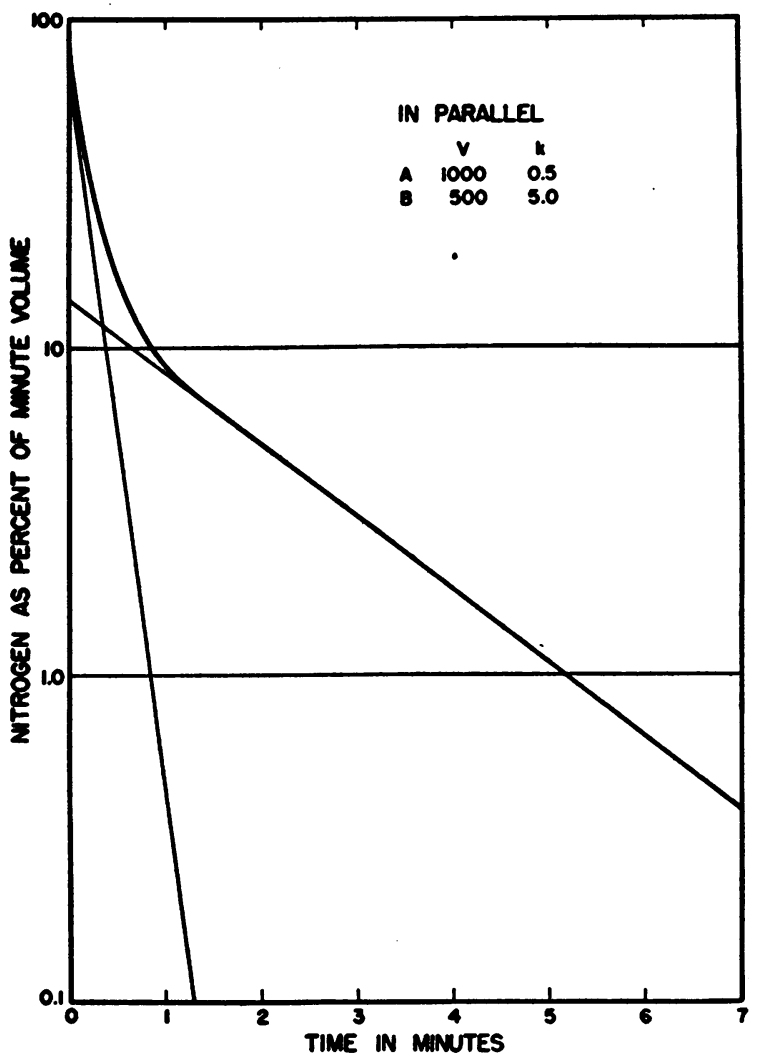

Fig. 3. Theoretical Rates of Nitrogen Elimination from Two Lung Spaces the Ventilation of Each OF WHICH IS INDEPENDENT OF THAT OF THE OTHER WITH Subject Breathing Pure Oxygen

The steep straight line represents the elimination from space $B$, having a volume of $500 \mathrm{cc}$. and a turnover rate of 5.0 times per minute. The other straight line represents the elimination from space $A$, having a volume of $1,000 \mathrm{cc}$. and a turnover rate of 0.5 times per minute. The curved line is the sum of the two straight lines and satisfies the equation:

$$
R / M \times 100=66 \mathrm{e}^{-8.0 t}+14 \mathrm{e}^{-0.5 t}
$$

in which $R$ is the rate of nitrogen elimination, $M$ is the respiratory minute volume, and time, 5 , is in minutes. where $X_{0}$ and $Y_{0}$ are concentrations at time zero. The significance of these solutions is best seen by filling some numbers into the equations and studying the resulting curves.

For example, if we arbitrarily assume that the lung consists of two spaces, the deep one, A (alveolar sacs), having a volume of $1,000 \mathrm{cc}$. and a turnover rate of 0.5 times per minute and the proximal one, $B$ (bronchioles), having a volume of $500 \mathrm{cc}$. and a turnover rate of 5.0 times per minute, Figures 3 and 4 compare the results of considering these spaces ventilated in parallel and in series.

Figure 3 is a semilogarithmic plot of Equation (4) with the nitrogen expressed as a fraction of the minute volume:

In parallel: $R / M=0.66 \mathrm{e}^{-5.0 t}+0.14 \mathrm{e}^{-0.6 t}$

The two straight lines represent the exponential terms and the curved line is their sum.

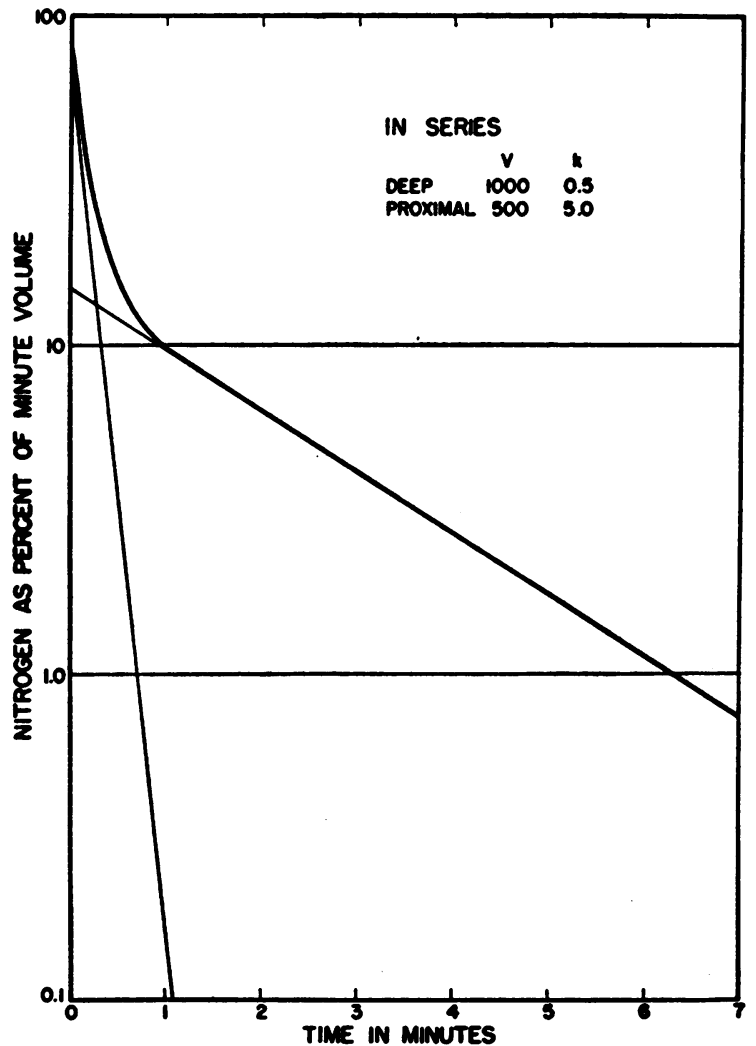

Fig. 4. Theoretical Rates of Nitrogen Elimination from the Same Two Spaces as in Figure 2 but Arranged so that All of the Air Ventilating the Deep Space Passes Through the Proximal Space

As explained in the text the resultant curve again has two components but here these represent events in the system as a whole rather than in the individual spaces. The volume obtained by integrating the flatter line is $40 \%$ greater than that assumed for the deeper space. The equation for the curved line is :

$$
R / M \times 100=65 e^{-0.00 t}+15 e^{-0.41 t}
$$

The curved line is observable experimentally. 
Similarly Figure 4 is a plot of Equation (9) with:

In series: $R / M=B=X=0.65 e^{-6.00 t}+0.15 e^{-0.41 t}$

The volume obtained by integrating the slow component of the in-series plot is $40 \%$ greater than that assumed for the deep space. This is part of the mechanism causing the apparent increase in the dead air space as noted by other authors. The identities of the spaces are thus lost, but the measure of their ventilation, the renewal rate, is obtained. Under these conditions (in-series ventilation) the total number of molecules entering and leaving a space, $k$, is not -equal to the renewal rate for that space because some molecules recirculate instead of leaving the system. If $100 \%$ were to recirculate, as can be approximated in very shallow, panting type respiration, no renewal would be achieved (except by diffusion) in the deeper spaces although appreciable quantities move in and out of them.

The situation is complicated by the nitrogen diffusing into the lungs from the tissues. The physiological theory and the rate of nitrogen removal from the tissues has been presented by one of us elsewhere $(14,15)$. This theory of gas exchange is based upon the experimental observation that the diffusion rates of inert gases do not influence their physiological exchange rates. The theory of Smith and Morales (16) in contrast is relatively weighted by a permeability factor influencing the exchange. We have used the theory and nitrogen exchange values given by Jones $(14,15)$.

In essence the theory states that the rate at which nitrogen is removed from a given tissue is proportional to the amount of nitrogen present in the tissue and to the blood perfusion factor, defined as the ratio of the volume of blood flow to the tissue per minute to the volume of the tissue. The solubility ratio and the perfusion factor can be combined in a single constant, $k$, the gas exchange coefficient. The definition leads to the expression

$$
\mathrm{R}=\mathrm{R}_{\mathrm{o}} \mathrm{e}^{-\mathbf{k t}}
$$

for the rate of removal of nitrogen from a given tissue. Since the tissues are circulated in parallel (with a few exceptions a given element of blood passes through only one set of capillaries in its course from the left ventricle to the right auricle) the expressions for the individual tissues can be summated to give the expression for the total body. Figure 5 is a plot of the removal rates for the individual tissues according to this scheme, with the curved line representing their sum and, therefore, the whole body. As here represented, this assumes that all of the nitrogen has been instantaneously removed from the lung spaces at time zero and that the nitrogen content of the arterial blood is zero. As an example of how one of these curves is obtained, the kidneys were assumed to have a combined volume of $270 \mathrm{cc}$. and a circulation of 1.33 liters of blood per minute. About $2.7 \mathrm{cc}$. of nitrogen will be originally present in the kidneys and since the solubility ratio is 1 and the perfusion ratio 4.9 , nitrogen will be removed from this tissue at a rate in cc./min. which is 4.9 times as great as the amount present in cc. Therefore the curve for the kidney is so drawn that the original rate of removal (the vertical intercept) is $13.3 \mathrm{cc} . / \mathrm{min}$. and decreases exponentially with a half-time of $0.693 / 4.9=0.14$ minutes. Al-

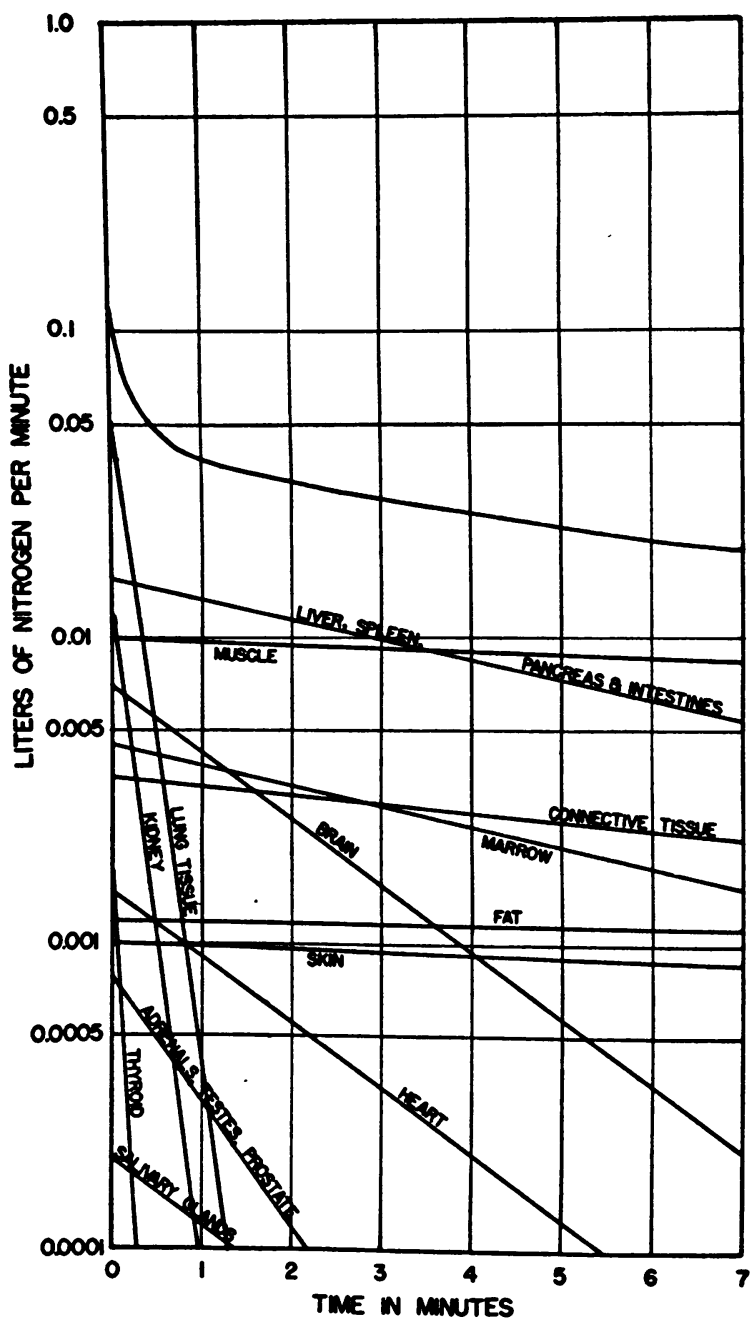

Fig. 5. Theoretical Rates of Nitrogen Elimination from Tissues of 70 Kilo Man with Cardiac OUtPUt of 5.89 Liters/Min. and Breathing Pure Oxygen, as Calculated from Tissue Volumes and Perfusion Factors Given by Jones $(14,15)$

Straight lines represent denitrogenation of individual tissues as calculated by method explained in the text. The curved line is the sum of all of the straight lines and is therefore the theoretical rate for the total body, assuming that the nitrogen originally in the lungs is washed out instantly at time zero.

though there is a comparatively large amount of nitrogen dissolved in the fatty tissues, this nitrogen is removed slowly because nitrogen is about five times as soluble in fat as in blood, which gives an unfavorable distribution coefficient, and because the perfusion factor for fat is also low.

In proceeding to considerations of a finite lung washing out period (and finite arterial nitrogen) equations of the same form as Equations (5) and (6) are obtained, with the tissues in a position analogous to the deeper space. Since, 
in general, the $k_{1}$ for the lung and the $k_{2}$ representing the total for the body will be quite different, and since $k_{2}$ will be small, the resulting components in the excretion rate curve will not be greatly different from those representing the processes independently and Jones's theory can be used directly to estimate the rate at which nitrogen is removed from the tissues. Figure 6 shows an experimentally obtained curve and the corresponding curve for the tissue theory, as adjusted for this individual's size. The area between these two curves represents the volume removed from the lung. The curve shown in Figure 7 is obtained by subtracting the tissue curve from the experimental one. The straight lines represent the components of this curve.

\section{DIFFUSION}

A factor involving diffusion in the alveoli or across the alveolar and capillary membranes has not been explicitly included in the theory just developed because experimental evidence indicates that it is not a limiting process.

M. Krogh (17) found that in one minute 20 to $30 \mathrm{cc}$. of carbon monoxide could diffuse from the spaces in an adult lung into the blood for each $\mathrm{mm}$. of $\mathrm{Hg}$ of difference in tension of carbon monoxide. The lesser solubility of nitrogen in water reduces the diffusion rate for nitrogen to about

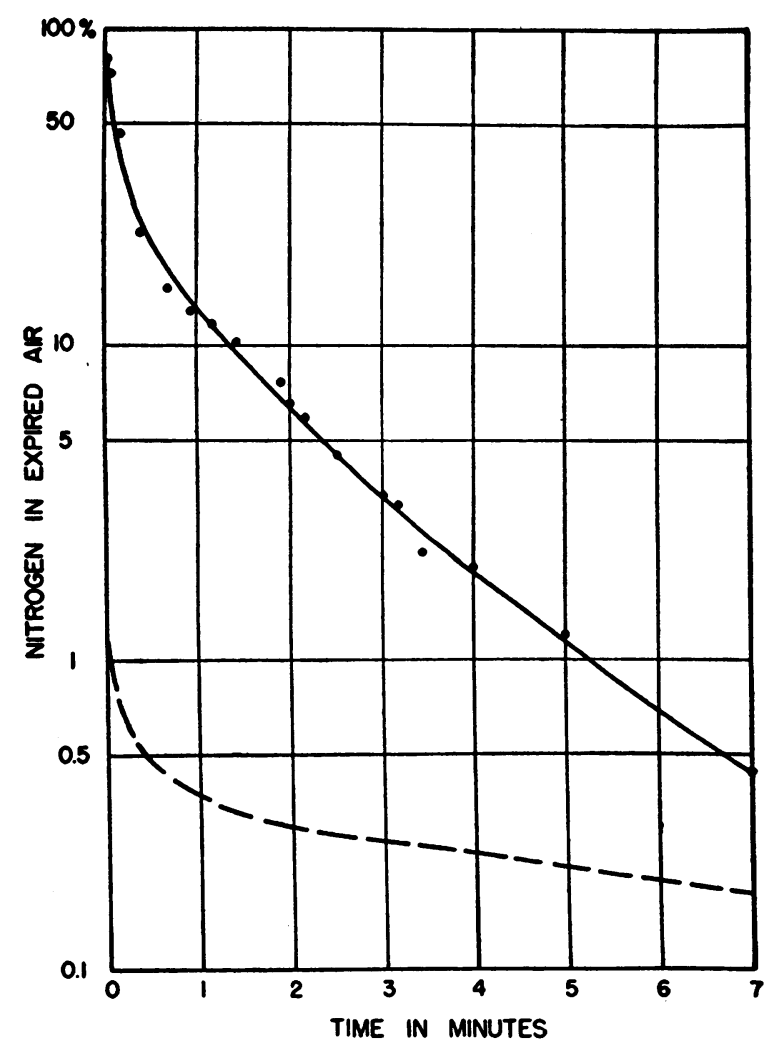

FIG. 6

Rate of denitrogenation, with subject breathing pure oxygen as obtained experimentally, shown as solid line, compared with theoretical rate of removal from tissues for same subject, shown as dashed line.
0.67 that of carbon monoxide, or 15 to $20 \mathrm{cc} . / \mathrm{min} . / \mathrm{mm}$. Therefore, at $573 \mathrm{~mm}$. of difference in tension nitrogen can diffuse into or out of the blood, depending upon the direction of the gradient, at a rate of 140 to $190 \mathrm{cc}$. $/ \mathrm{sec}$. However, only $0.57 \mathrm{cc}$. of nitrogen can be absorbed in the $60 \mathrm{cc}$. of blood that is in the capillaries at any instant according to the determination by Roughton (18) that the blood remains in the capillaries of the order of $0.75 \pm 0.25$ seconds. Therefore nitrogen can diffuse out of the blood at a rate in cc./sec. whose magnitude is about 300 times that of the amount present in cc. and as the blood passes along the capillaries the tension of nitrogen in the blood will rapidly fall toward equilibrium with the tension in the alveoli. If Henry's law holds and if the rate of diffusion is always proportional to the amount present in excess of equilibrium and hence to the tension difference, the tension will fall exponentially as $\mathrm{P}=\mathrm{P}_{0} \mathrm{e}^{-k t}$, where $\mathrm{P}$ is the tension difference at any time, $P_{0}$ is $P$ at time zero taken as the instant a given portion of the blood enters the capillaries, $k$ is the proportionality between the rate of diffusion in $\mathrm{cc} . / \mathrm{sec}$. and the amount present in cc., and $t$ is time in seconds. Using $k=100 \mathrm{sec}^{-1}$ to be conservative it is seen that in

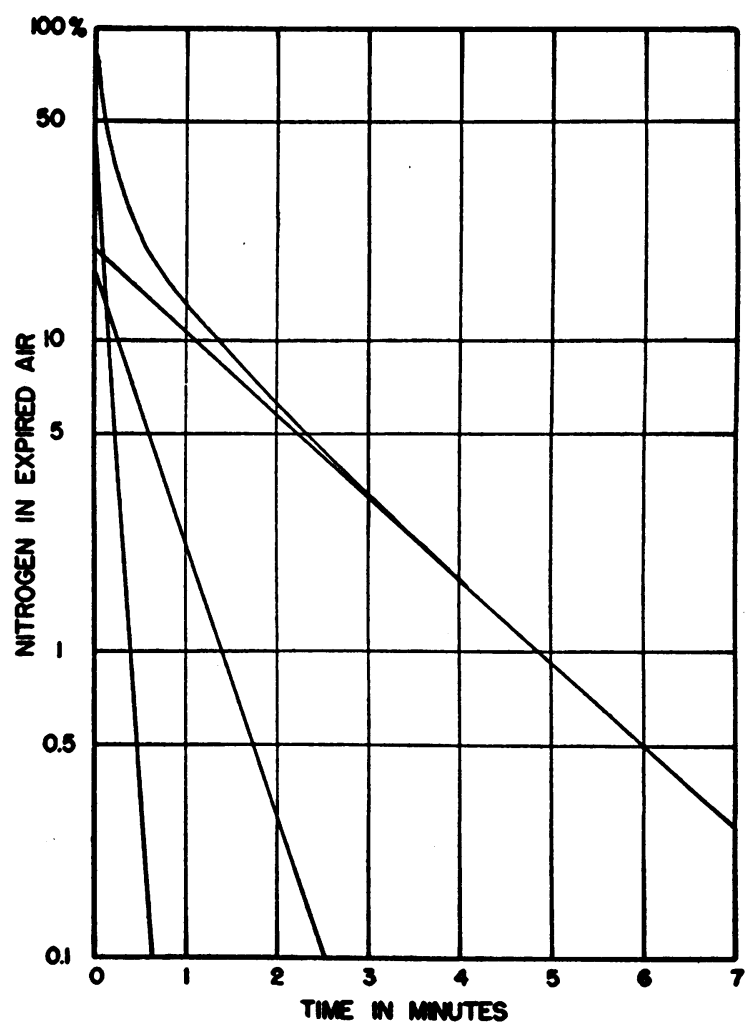

Fre. 7

Curved line represents curve obtained by subtracting values along dashed line in Figure 5 from those of solid line in Figure 5 and is therefore the rate of washing out from the lung as an independent entity. Straight lines are the components of the curved line as obtained by graphical analysis and give the turnover rates in the lung. 
0.1 second the tension difference can fall to 0.000045 of its value at time zero and we have every reason to believe that essential equilibrium can be attained in the 0.75 second the blood is in the capillaries. This result applies equally well to smaller initial differences in tension for in these cases the amount of nitrogen in excess of equilibrium is reduced proportionally.

Harrop and Heath (19), using carbon monoxide, found low diffusion constants for oxygen in subjects afflicted with polycythemia vera, and suggest that this results in a lowered oxygen tension in the arterial blood and may be an etiological factor in this disease. In terms of nitrogen, however, their results give values of about $10 \mathrm{cc} . / \mathrm{min} . / \mathrm{mm}$. and this is not enough of a reduction to interfere with the rapid approach to equilibrium. The possibility of there being a defect of lung ventilation contributing to the finding of a low diffusion constant is considered in the present studies.

Jones's experiments $(14,15)$ with radioactive nitrogen and xenon showed that the desaturation curves for these two gases would be identical if their solubilities were equal. This is interpreted as showing that neither diffusion in the lung, as across the alveolar sacs, nor diffusion across the alveolar and capillary membranes is a limiting process, for if it were, then the difference in the molecular weights of these gases would have affected the curves.

Riley and Cournand (10) in developing the concept of an "ideal" alveolar air indicate how differences between the tension in the mixed arterial blood and that in the alveoli may arise from differences in the ventilationperfusion ratio without the existence of a failure of diffusion to establish equilibrium in the alveoli.

Other experiments have shown how great a role it is possible for diffusion to play. Roth, Whitehead, and Draper (20) found that dogs can survive for as long as 45 minutes when the respiratory movements have been arrested by sodium pentothal anesthesia if the dogs are in an oxygen atmosphere and the lungs have previously been filled with pure oxygen. Their explanation that the removal of oxygen by the hemoglobin reduces the pressure in the alveoli so that oxygen flows into these spaces as a consequence of the pressure difference seems to be correct. Under these conditions diffusion is responsible for the transfer of oxygen only across the alveolar sac and possibly through the respiratory bronchioles; the flow through the trachea and bronchi is the result of a pressure difference. The results indicate that this process may even be of importance during normal respiration, but this has not been evaluated. Of course this mechanism holds only for oxygen, and does not apply to the removal of carbon dioxide or the transfer of nitrogen.

Since all evidence indicates that diffusion is not a limiting process it is not necessary to describe it explicitly; it is implicitly included in the other theories.

\section{TREATMENT OF THE DATA}

In accordance with the theory just outlined the rate curve is plotted on semilogarithmic paper to facilitate analysis into exponential components, after correction for the tissue nitrogen. Integration of these components over the interval from zero to infinite time gives the volume of nitrogen associated with each turnover rate and the total of these volumes $\times 5 / 4$ gives the lung volume. The volume obtained in this way corresponds to the volume commonly designated as the "functional residual air" (F.R.A.), or as the "respiratory resting level." The columns headed $k$ and $f$ in Tables I-IV represent the components of the rate curve expressed as the turnover rates, $k$, and the fraction, $f$, of the lung volume associated with these turnover rates. From these data the original curve can be reconstructed by a reversal of the analytical procedure. The $R_{0}$ for a given component is equal to $\mathrm{kv}$ and the slope is most conveniently expressed as the half time, $t_{1 / 2}=.693 / \mathrm{k}$.

With the data in this form, it is still difficult to compare the ventilation of one lung with that of another because both the fractions and the turnover rates vary.

However, if we consider the ventilation of the lung as a whole, this difficulty can be avoided. The average time that a molecule remains in a space is the reciprocal of the turnover rate. By weighting these average times according to the fraction of the lung volume with which they are associated we obtain the average time for the entire lung. The reciprocal of this may in turn be regarded as the average turnover rate achieved for the lung as a whole, thus

where

$$
\frac{1}{K}=\frac{f_{1}}{k_{1}}+\frac{f_{2}}{k_{2}}+\frac{f_{3}}{k_{3}}
$$

$$
f_{1}+f_{2}+f_{3}=1
$$

If the entire lung were uniformly ventilated with a turnover rate of $\mathrm{K}$ times per minute, the average time which a molecule would remain in the lung would be the same as that actually obtaining with several fractions of the lung being ventilated at different rates.

In contrast to this we have the ratio of the respiratory minute volume to the lung volume (FRA), which sets an upper limit on the average turnover rate. Therefore if we divide the turnover rate achieved, $K$, by the ratio of the minute volume to the lung volume, we have a measure $E$ of the efficiency of ventilation in the sense that we are comparing achievement to effort. The number $\mathrm{E}$ is also a measure of the uniformity of mixing since it is the deviation from uniformity of distribution which lowers the efficiency.

\section{RESULTS AND DISCUSSION}

Repeated tests on the same individual show considerable variation in the turnover rates and their associated volumes. A measure of the repeatability of the test is required if conclusions are to be drawn in comparing different individuals.

Table I presents the values for $K, M V / F R A$, and $E$ as derived from the results of repeated tests on subjects. Test and retest in this series were all made in the morning and within a week of each other. Statistical analysis of such a small series is of doubtful significance, but the standard deviations and the reliabilities as corrected for small series are given. 
TABLE I

Comparison of ventilatory characteristics found in test and retest under similar conditions

\begin{tabular}{l|r|r|r|r|r|r}
\hline \hline Subject & $\mathrm{K}_{*}$ & $\frac{\mathrm{MV}}{\text { FRAs }}$ & $\mathrm{E}_{\boldsymbol{z}}$ & $\mathrm{K}_{\boldsymbol{y}}$ & $\frac{\mathrm{MV}}{\text { FRA }_{y}}$ & $\mathrm{E}_{\boldsymbol{y}}$ \\
\hline JD & 1.26 & 2.20 & .57 & 1.14 & 2.30 & .50 \\
JR & 1.96 & 3.03 & .65 & 1.52 & 3.80 & .40 \\
WP & 1.35 & 3.46 & .39 & 2.40 & 6.00 & .40 \\
LMA & 2.12 & 4.04 & .52 & 2.53 & 3.61 & .69 \\
LM & 1.12 & 2.80 & .40 & 1.56 & 3.10 & .50 \\
WCW & .42 & 1.20 & .35 & .65 & 1.85 & .34 \\
FB & .89 & 1.80 & .49 & .83 & 1.08 & .44 \\
WEB & 1.18 & 1.96 & .65 & 1.09 & 1.80 & .61 \\
LMJ & .57 & 2.49 & .23 & .71 & 2.20 & .31 \\
WLM & .47 & 1.68 & .28 & .34 & 2.32 & .15 \\
\hline Mean & 1.27 & 2.89 & .434 & 1.13 & 2.47 & .453 \\
s & .74 & 1.33 & .174 & .60 & .88 & .166 \\
r & .67 & .68 & .41 & & & \\
\hline
\end{tabular}

$\mathrm{K}$ Ventilatory coefficient achieved in turnovers/ minute.

MV/FRA Ratio of minute volume to lung volume-upper limit of ventilatory coefficient.

E Efficiency.

s Standard deviation.

r Reliability.
Tables II-V present the data obtained on 55 resting subjects, with the polycythemic group being subdivided according to sex. Data are listed for the age, height, weight, respiratory rate, vital capacity, FRA volume, curve analysis, and the values for $K, M V / F R A$, and $E$ for each subject. The FRA volume given is that obtained by calculating the total nitrogen originally present in the lung by integration of the rate curve and multiplying by 1.25 , the reciprocal of 0.80 . None of the volumes is corrected.

The turnover rates and their associated fractions are tabulated in four columns according to whether $a$ ) $\mathrm{k}$ is greater than $2, b$ ) between 2 and $1, c)$ between 1 and 0.5 , or $d$ ) less than 0.5 .

Comparison of the averages for the analysis shows that in the normal and polycythemic groups over $50 \%$ of the lung is ventilated with a $\mathrm{k}$ greater than one, the sum of the averages for columns $A$ and $B$ being $69 \%$ for the normals, $57 \%$ for the

TABLE II

Lung ventilation data and characteristics for normal subjects at rest and with normal respiratory rate

\begin{tabular}{|c|c|c|c|c|c|c|c|c|c|c|c|c|c|c|c|c|c|c|c|c|}
\hline & \multirow{2}{*}{ Age } & \multirow{2}{*}{ Ht } & \multirow{2}{*}{$\mathbf{W t}$} & \multirow{2}{*}{$\mathbf{M V}$} & \multirow{2}{*}{$\mathbf{N}$} & \multirow{2}{*}{ vc } & \multirow{2}{*}{ FRA } & \multicolumn{4}{|c|}{ A } & \multicolumn{2}{|c|}{ B } & \multicolumn{2}{|c|}{ C } & \multicolumn{2}{|c|}{ D } & \multirow{2}{*}{$\mathbf{K}$} & \multirow{2}{*}{$\frac{\text { MV }}{\text { FRA }}$} & \multirow{2}{*}{$\mathbf{E}$} \\
\hline & & & & & & & & k & f & $k$ & f & $k$ & f & $k$ & $\mathrm{f}$ & $k$ & f & & & \\
\hline $\begin{array}{l}\text { JD } \\
\text { EP } \\
\text { FB } \\
\text { IK } \\
\text { CA }\end{array}$ & $\begin{array}{l}26 \\
29 \\
38 \\
40 \\
29\end{array}$ & $\begin{array}{l}5-6 \\
5-11 \\
5-6 \\
5-7 \\
6-2\end{array}$ & $\begin{array}{l}132 \\
155 \\
135 \\
155 \\
207\end{array}$ & $\begin{array}{r}6.00 \\
15.00 \\
8.90 \\
6.00 \\
8.30\end{array}$ & $\begin{array}{r}12 \\
14 \\
8 \\
7 \\
9\end{array}$ & $\begin{array}{l}2.50 \\
4.30 \\
3.50 \\
4.30\end{array}$ & $\begin{array}{l}2.75 \\
5.55 \\
4.95 \\
4.75 \\
3.10\end{array}$ & $\begin{array}{l}2.9 \\
6.9 \\
9.9 \\
5.7 \\
3.3\end{array}$ & $\begin{array}{l}.64 \\
.14 \\
.10 \\
.06 \\
.74\end{array}$ & & & $\begin{array}{l}1.5 \\
2.0 \\
1.3\end{array}$ & $\begin{array}{l}.75 \\
.20 \\
.62\end{array}$ & \begin{tabular}{|l|}
1.0 \\
.63 \\
.53 \\
.86
\end{tabular} & $\begin{array}{l}.36 \\
.70 \\
.32 \\
.26\end{array}$ & .43 & .10 & \begin{tabular}{|r|}
1.26 \\
1.85 \\
.89 \\
.93 \\
1.92
\end{tabular} & \begin{tabular}{|l|}
2.20 \\
2.70 \\
1.80 \\
1.25 \\
2.67
\end{tabular} & $\begin{array}{l}.57 \\
.69 \\
.49 \\
.74 \\
.72\end{array}$ \\
\hline $\begin{array}{l}\text { DC } \\
\text { KS } \\
\text { GE } \\
\text { MFC } \\
\text { SA }\end{array}$ & $\begin{array}{l}56 \\
39 \\
50 \\
35 \\
33\end{array}$ & $\begin{array}{l}5-10 \\
5-10 \\
5-10 \\
6-0 \\
5-9\end{array}$ & $\begin{array}{l}143 \\
203 \\
180 \\
180 \\
160\end{array}$ & $\begin{array}{r}9.00 \\
10.80 \\
11.00 \\
9.00\end{array}$ & $\begin{array}{r}7 \\
8 \\
17 \\
11\end{array}$ & $\begin{array}{l}4.90 \\
3.00\end{array}$ & \begin{tabular}{|l|}
5.10 \\
2.85 \\
\\
5.45 \\
3.00
\end{tabular} & $\begin{array}{r}5.7 \\
13.8 \\
13.8 \\
4.9 \\
11.5\end{array}$ & $\begin{array}{l}.10 \\
.14 \\
.13 \\
.07 \\
.15\end{array}$ & $\begin{array}{l}3.6 \\
2.1 \\
2.9\end{array}$ & $\begin{array}{l}.32 \\
.47 \\
.27\end{array}$ & 1.6 & .93 & .88 & .58 & $\begin{array}{l}.31 \\
.43 \\
.33\end{array}$ & $\begin{array}{l}.18 \\
.54 \\
.40\end{array}$ & \begin{tabular}{|r|}
.95 \\
.78 \\
.69 \\
1.69 \\
1.30
\end{tabular} & $\begin{array}{l}1.76 \\
3.34 \\
2.92 \\
2.02 \\
3.00\end{array}$ & $\begin{array}{l}.54 \\
.23 \\
.24 \\
.84 \\
.43\end{array}$ \\
\hline $\begin{array}{l}\text { LF } \\
\text { WEB } \\
\text { JSR } \\
\text { HLM } \\
\text { RCK }\end{array}$ & $\begin{array}{l}28 \\
28 \\
27 \\
50 \\
26\end{array}$ & $\begin{array}{l}5-7 \\
5-9 \\
5-10 \\
5-10 \\
6-0\end{array}$ & \begin{tabular}{|l|}
143 \\
151 \\
150 \\
175 \\
182
\end{tabular} & \begin{tabular}{|r|}
12.00 \\
9.50 \\
9.80 \\
9.40
\end{tabular} & $\begin{array}{l}15 \\
13 \\
13 \\
12\end{array}$ & $\begin{array}{l}3.00 \\
4.20 \\
4.10\end{array}$ & $\begin{array}{l}3.10 \\
3.15 \\
2.80 \\
2.75\end{array}$ & $\begin{array}{r}6.3 \\
9.9 \\
4.6 \\
11.5 \\
4.3\end{array}$ & $\begin{array}{l}.48 \\
.06 \\
.37 \\
.20 \\
.65\end{array}$ & $\begin{array}{l}2.2 \\
2.2 \\
2.6 \\
2.1\end{array}$ & $\begin{array}{l}.35 \\
.44 \\
.49 \\
.52\end{array}$ & 1.6 & .35 & .80 & .50 & $\begin{array}{l}.50 \\
.49 \\
.37\end{array}$ & $\begin{array}{l}.16 \\
.12 \\
.29\end{array}$ & \begin{tabular}{|l|}
1.82 \\
1.18 \\
1.96 \\
.95 \\
2.70
\end{tabular} & \begin{tabular}{|l|}
3.88 \\
1.96 \\
3.03 \\
5.50 \\
3.40
\end{tabular} & $\begin{array}{l}.47 \\
.60 \\
.65 \\
.27 \\
.80\end{array}$ \\
\hline $\begin{array}{l}\text { DW } \\
\text { GP } \\
\text { AHS }\end{array}$ & $\begin{array}{l}27 \\
18 \\
32\end{array}$ & $\begin{array}{l}6-2 \\
6-1 \\
5-11\end{array}$ & $\begin{array}{l}153 \\
165 \\
178\end{array}$ & $\begin{array}{r}8.00 \\
10.20\end{array}$ & $\begin{array}{l}11 \\
12\end{array}$ & $\begin{array}{l}4.00 \\
4.80\end{array}$ & $\begin{array}{l}4.45 \\
2.45\end{array}$ & $\begin{array}{r}3.6 \\
3.3 \\
11.5\end{array}$ & $\begin{array}{l}.34 \\
.40 \\
.27\end{array}$ & & & $\begin{array}{l}1.2 \\
2.0\end{array}$ & $\begin{array}{l}.66 \\
.53\end{array}$ & .75 & .60 & .49 & .20 & $\begin{array}{l}1.56 \\
1.09 \\
1.45\end{array}$ & \begin{tabular}{|l|}
2.01 \\
1.80 \\
2.13
\end{tabular} & $\begin{array}{l}.78 \\
.61 \\
.68\end{array}$ \\
\hline $\begin{array}{r}\text { Mean } \\
\text { s }\end{array}$ & $\begin{array}{l}34 \\
10\end{array}$ & $\begin{array}{c}5-10 \\
-2\end{array}$ & $\begin{array}{r}163 \\
30\end{array}$ & $\begin{array}{l}9.50 \\
2.15\end{array}$ & $\begin{array}{r}11 \\
3\end{array}$ & $\begin{array}{r}3.90 \\
.50\end{array}$ & $\begin{array}{l}3.75 \\
1.05\end{array}$ & Mean & $\mathrm{n}$ for & 18 & .44 & & .27 & & .18 & & .11 & $\begin{array}{r}1.39 \\
.51\end{array}$ & $\begin{array}{r}2.52 \\
.65\end{array}$ & $\begin{array}{l}.57 \\
.20\end{array}$ \\
\hline
\end{tabular}

Age in years.

Height in feet and inches.

Weight in pounds.

$\mathrm{MV}=$ Minute volume in liters (not corrected).

$\mathrm{N}=$ Number of respirations per minute.

VC = Vital capacity in liters (not corrected).

FRA = Lung volume in liters as calculated by integration (not corrected). $\mathbf{k}=$ Ventilation coefficient for individual component in turnovers per minute.

f $\quad=$ Decimal fraction of lung capacity associated with corresponding $\mathbf{k}$.

$\mathrm{K}=$ Effective coefficient of ventilation

$\mathrm{E}=$ Efficiency of ventilation.

$\begin{array}{ll}\mathrm{E} & =\text { Efficiency of ventilation } \\ \mathrm{s} & =\text { Standard deviation. }\end{array}$ 
TABLE III

Lung ventilation data and characteristics for male subjects with polycythemia vera at rest and with normal respiratory rate

\begin{tabular}{|c|c|c|c|c|c|c|c|c|c|c|c|c|c|c|c|c|c|c|c|c|}
\hline & \multirow{2}{*}{ Age } & \multirow{2}{*}{$\mathbf{H t}$} & \multirow{2}{*}{$\mathbf{W t}$} & \multirow{2}{*}{ MV } & \multirow{2}{*}{$\mathbf{N}$} & \multirow{2}{*}{ vC } & \multirow{2}{*}{ FRA } & \multicolumn{4}{|c|}{$\mathbf{A}$} & \multicolumn{2}{|c|}{ B } & \multicolumn{2}{|c|}{ C } & \multicolumn{2}{|c|}{ D } & \multirow{2}{*}{$\mathbf{K}$} & \multirow{2}{*}{$\frac{\text { MV }}{\text { FRA }}$} & \multirow{2}{*}{$\mathbf{E}$} \\
\hline & & & & & & & & $k$ & $\mathbf{f}$ & $\mathbf{k}$ & f & $k$ & f & k & f & $k$ & f & & & \\
\hline $\begin{array}{l}\text { JG } \\
\text { GT } \\
\text { PN } \\
\text { HF } \\
\text { EJG }\end{array}$ & $\begin{array}{l}53 \\
45 \\
58 \\
45 \\
57\end{array}$ & $\begin{array}{l}5-10 \\
5-10 \\
5-10 \\
5-6 \\
5-11\end{array}$ & $\begin{array}{l}185 \\
155 \\
173 \\
185 \\
210\end{array}$ & $\begin{array}{r}10.30 \\
10.20 \\
8.80 \\
7.90 \\
6.80\end{array}$ & $\begin{array}{r}14 \\
18 \\
13 \\
18 \\
7\end{array}$ & $\begin{array}{l}3.00 \\
3.30 \\
3.00 \\
3.60 \\
2.70\end{array}$ & $\begin{array}{l}5.80 \\
3.20 \\
4.60 \\
3.40 \\
4.80\end{array}$ & $\begin{array}{l}4.6 \\
6.9 \\
8.0 \\
3.1 \\
2.3\end{array}$ & $\begin{array}{l}.31 \\
.30 \\
.13 \\
.71 \\
.44\end{array}$ & & & $\begin{array}{l}1.38 \\
1.57\end{array}$ & $\begin{array}{l}.16 \\
.70\end{array}$ & $\begin{array}{l}1.0 \\
.70\end{array}$ & $\begin{array}{l}.87 \\
.56\end{array}$ & $\begin{array}{l}.21 \\
.38\end{array}$ & $\begin{array}{l}.54 \\
.29\end{array}$ & $\begin{array}{l}.37 \\
2.20 \\
1.14 \\
1.01 \\
1.01\end{array}$ & $\begin{array}{l}1.76 \\
3.16 \\
1.91 \\
2.34 \\
1.41\end{array}$ & $\begin{array}{l}.21 \\
.70 \\
.59 \\
.43 \\
.75\end{array}$ \\
\hline $\begin{array}{l}\text { WCW } \\
\text { CPR } \\
\text { CTC } \\
\text { WLM } \\
\text { ARO }\end{array}$ & $\begin{array}{l}75 \\
58 \\
38 \\
65 \\
44\end{array}$ & $\begin{array}{l}6-0 \\
6-0 \\
5-4 \\
6-2 \\
5-6\end{array}$ & $\begin{array}{l}135 \\
200 \\
146 \\
180 \\
155\end{array}$ & $\begin{array}{r}5.20 \\
8.50 \\
8.50 \\
13.20 \\
9.10\end{array}$ & $\begin{array}{r}7 \\
18 \\
12 \\
12 \\
24\end{array}$ & $\begin{array}{l}3.80 \\
3.90 \\
2.80 \\
3.30\end{array}$ & $\begin{array}{l}4.40 \\
4.95 \\
2.70 \\
7.85 \\
3.20\end{array}$ & $\begin{array}{r}13.8 \\
8.6 \\
4.3 \\
8.6 \\
8.6\end{array}$ & $\begin{array}{l}.04 \\
.07 \\
.59 \\
.10 \\
.14\end{array}$ & $\begin{array}{l}2.6 \\
2.5 \\
2.0\end{array}$ & $\begin{array}{l}.28 \\
.22 \\
.69\end{array}$ & $\begin{array}{l}1.8 \\
1.4 \\
1.4\end{array}$ & $\begin{array}{l}.14 \\
.41 \\
.17\end{array}$ & $\begin{array}{l}.86 \\
.60\end{array}$ & $\begin{array}{l}.30 \\
.65\end{array}$ & $\begin{array}{l}.27 \\
.35\end{array}$ & $\begin{array}{l}.52 \\
.67\end{array}$ & $\begin{array}{r}.42 \\
.83 \\
2.32 \\
.47 \\
1.72\end{array}$ & $\begin{array}{l}1.20 \\
1.71 \\
3.11 \\
1.68 \\
2.84\end{array}$ & $\begin{array}{l}.35 \\
.48 \\
.75 \\
.28 \\
.61\end{array}$ \\
\hline $\begin{array}{l}\text { CH } \\
\text { AA } \\
\text { AWB } \\
\text { LMA } \\
\text { MA }\end{array}$ & $\begin{array}{l}70 \\
33 \\
56 \\
67 \\
47\end{array}$ & $\begin{array}{l}6-2 \\
6-0 \\
5-8 \\
5-8\end{array}$ & $\begin{array}{l}153 \\
160 \\
170 \\
158 \\
144\end{array}$ & $\begin{array}{r}7.70 \\
7.00 \\
10.20 \\
8.70 \\
9.80\end{array}$ & $\begin{array}{r}11 \\
\\
5 \\
16\end{array}$ & $\begin{array}{l}1.50 \\
2.70 \\
2.50\end{array}$ & $\begin{array}{l}8.20 \\
3.75 \\
3.75 \\
2.15 \\
4.95\end{array}$ & \begin{tabular}{r|}
6.9 \\
12.7 \\
17.0 \\
9.9 \\
9.9
\end{tabular} & $\begin{array}{l}.10 \\
.57 \\
.07 \\
.30 \\
.12\end{array}$ & 2.5 & .45 & $\begin{array}{l}1.6 \\
1.5\end{array}$ & $\begin{array}{l}.04 \\
\\
.70 \\
.37\end{array}$ & $\begin{array}{l}.66 \\
.79\end{array}$ & $\begin{array}{l}.43 \\
.48\end{array}$ & .38 & .51 & $\begin{array}{r}.26 \\
1.16 \\
1.26 \\
2.12 \\
.61\end{array}$ & $\begin{array}{r}.94 \\
1.86 \\
2.71 \\
4.04 \\
1.98\end{array}$ & $\begin{array}{l}.28 \\
.62 \\
.47 \\
.52 \\
.31\end{array}$ \\
\hline $\begin{array}{l}\text { AJT } \\
\text { SJ }\end{array}$ & $\begin{array}{l}66 \\
57\end{array}$ & $\begin{array}{l}5-11 \\
5-6\end{array}$ & $\begin{array}{l}170 \\
137\end{array}$ & $\begin{array}{r}9.80 \\
11.40\end{array}$ & $\begin{array}{l}10 \\
18\end{array}$ & $\begin{array}{l}4.50 \\
3.20\end{array}$ & $\begin{array}{l}5.60 \\
6.60\end{array}$ & $\begin{array}{l}5.3 \\
2.5\end{array}$ & $\begin{array}{l}.23 \\
.65\end{array}$ & & & & & $\begin{array}{l}.48 \\
.27\end{array}$ & $\begin{array}{l}.77 \\
.35\end{array}$ & & & $\begin{array}{l}.61 \\
.61\end{array}$ & $\begin{array}{l}1.75 \\
1.71\end{array}$ & $\begin{array}{l}.35 \\
.36\end{array}$ \\
\hline $\begin{array}{r}\text { Mean } \\
\text { s }\end{array}$ & $\begin{array}{l}53 \\
13\end{array}$ & $\begin{array}{r}5-9 \\
-4\end{array}$ & $\begin{array}{r}166 \\
17\end{array}$ & $\begin{array}{l}9.30 \\
1.50\end{array}$ & $\begin{array}{r}13 \\
5\end{array}$ & $\begin{array}{r}3.40 \\
.20\end{array}$ & $\begin{array}{l}4.75 \\
1.60\end{array}$ & Mear & n for & 17 & .33 & & .24 & & .17 & & .25 & $\begin{array}{r}1.07 \\
.60\end{array}$ & $\begin{array}{r}2.15 \\
.79\end{array}$ & $\begin{array}{l}.48 \\
.17\end{array}$ \\
\hline
\end{tabular}

Age in years.

Height in feet and inches.

Weight in pounds

MV = Minute volume in liters (not corrected).

$\mathrm{N}=$ Number of respirations per minute.

VC $=$ Vital capacity in liters (not corrected).

FRA = Lung volume in liters as calculated by integration (not corrected).

polycythemic men, and $55 \%$ for the polycythemic women. The lung pathology group shows a reverse distribution with nearly $50 \%$ of the volume being associated with a turnover rate of less than 0.5 and a total of $58 \%$ less than 1.0. The derived numbers, $K, M V / F R A$, and $E$ must be used in going beyond such simple comparisons. The averages and the standard deviations for these are given for each group in the table. The differences between the normals and the polycythemics lose what little significance they may appear to have when the factor of age is considered.

The correlations with age for $\mathrm{K}$ are normal, -.60 , male polycythemics, -.45 , female polycythemics, -.51 , lung pathology, +.46 , and for the normals and polycythemics combined, -.60 . With the other data these figures show that there is no difference between the effectiveness of the ventilation of the lung in the polycythemic group and that in the normal group, except as is due to the difference in the means of the ages of these k $=$ Ventilation coefficient for individual component in turnovers per minute.

f $\quad=$ Decimal fraction of lung capacity associated with corresponding $\mathbf{k}$.

$\mathrm{K}=$ Effective coefficient of ventilation.

$\mathrm{E}=$ Efficiency of ventilation.

s $=$ Standard deviation.

groups. On the other hand, in the lung pathology group, the correlation with age is actually reversed, with the younger subjects having less effective ventilation than the older ones. The most poorly ventilated lung in the entire series is that of EG. With a minute volume of 11 liters this individual achieved an effective turnover rate of only .11 , establishing a low for efficiency also. Low effectiveness is not necessarily the result of low efficiency, as seen in the case of DP, a polycythemic female, who has $88 \%$ of the lung ventilated with a turnover rate of only $0.28 / \mathrm{min}$., but who accomplishes this with the same efficiency as the average for the normal group. In general, however, the two do go together.

The value for $E$, the efficiency, seems to be an index of physical fitness. The younger, more vigorous normals have consistently high efficiencies, while those out of condition have lower efficiencies. The highest efficiency found was in the case of MFC, a guard, and the next was in the 
TABLE IV

Lung ventilation data and characteristics for female subjects with polycythemia vera at rest and with normal respiratory rate

\begin{tabular}{|c|c|c|c|c|c|c|c|c|c|c|c|c|c|c|c|c|c|c|c|c|}
\hline & \multirow{2}{*}{ Age } & \multirow{2}{*}{$\mathbf{H t}$} & \multirow{2}{*}{$W_{t}$} & \multirow{2}{*}{ MV } & \multirow{2}{*}{$\mathbf{N}$} & \multirow{2}{*}{ vc } & \multirow{2}{*}{ FRA } & \multicolumn{4}{|c|}{$\mathbf{A}$} & \multicolumn{2}{|c|}{ B } & \multicolumn{2}{|c|}{ C } & \multicolumn{2}{|c|}{ D } & \multirow{2}{*}{$\mathbf{K}$} & \multirow{2}{*}{$\frac{M V}{\text { FRA }}$} & \multirow{2}{*}{$\mathbf{E}$} \\
\hline & & & & & & & & $\mathbf{k}$ & f & k & f & $\mathbf{k}$ & f & k & f & k & f & & & \\
\hline $\begin{array}{l}\text { MJT } \\
\text { LMJ } \\
\text { ALM } \\
\text { AWM } \\
\text { ENW }\end{array}$ & $\begin{array}{l}33 \\
68 \\
58 \\
63 \\
69\end{array}$ & $\begin{array}{l}5-2 \\
5-1 \\
5-5 \\
5-6 \\
5-4\end{array}$ & $\begin{array}{l}160 \\
112 \\
155 \\
126 \\
110\end{array}$ & $\begin{array}{r}11.40 \\
9.00 \\
5.00\end{array}$ & $\begin{array}{r}12 \\
12 \\
15 \\
11 \\
9\end{array}$ & $\begin{array}{l}1.50 \\
2.00 \\
2.30 \\
1.90\end{array}$ & $\begin{array}{l}7.70 \\
3.60 \\
4.20 \\
4.70\end{array}$ & $\begin{array}{l}2.8 \\
6.3 \\
5.3 \\
2.9 \\
2.0\end{array}$ & $\begin{array}{l}.30 \\
.27 \\
.14 \\
.20 \\
.32\end{array}$ & 2.2 & .36 & $\begin{array}{l}1.2 \\
1.77\end{array}$ & $\begin{array}{l}.40 \\
.41\end{array}$ & .72 & .86 & $\begin{array}{l}.27 \\
.20 \\
.46 \\
.40\end{array}$ & $\begin{array}{l}.30 \\
.32 \\
.44 \\
.68\end{array}$ & $\begin{array}{l}.65 \\
.57 \\
.82 \\
.84 \\
.55\end{array}$ & $\begin{array}{l}1.35 \\
2.49 \\
1.19 \\
1.57 \\
1.30\end{array}$ & $\begin{array}{l}.50 \\
.23 \\
.69 \\
.53 \\
.42\end{array}$ \\
\hline $\begin{array}{l}\text { EK } \\
\text { LJ } \\
\text { RI } \\
\text { CS } \\
\text { LM }\end{array}$ & $\begin{array}{l}44 \\
30 \\
52 \\
57 \\
54\end{array}$ & $\begin{array}{l}5-2 \\
5-6 \\
5-6 \\
5-0 \\
5-4\end{array}$ & $\begin{array}{l}130 \\
125 \\
142 \\
135 \\
146\end{array}$ & $\begin{array}{l}6.00 \\
6.30 \\
6.20 \\
7.00 \\
6.50\end{array}$ & $\begin{array}{r}13 \\
14 \\
15 \\
18 \\
8\end{array}$ & $\begin{array}{l}2.45 \\
2.30 \\
1.75 \\
1.50 \\
3.20\end{array}$ & $\begin{array}{l}4.40 \\
2.40 \\
3.10 \\
2.95 \\
2.35\end{array}$ & \begin{tabular}{|r|}
4.6 \\
7.7 \\
3.8 \\
4.6 \\
13.8
\end{tabular} & $\begin{array}{l}.12 \\
.17 \\
.32 \\
.39 \\
.06\end{array}$ & $\begin{array}{l} \\
3.8\end{array}$ & .34 & $\begin{array}{l}1.1 \\
1.3 \\
1.2\end{array}$ & $\begin{array}{l}.45 \\
.83 \\
.68\end{array}$ & $\begin{array}{l}.75 \\
.93 \\
.75\end{array}$ & $\begin{array}{l}.44 \\
\\
.61 \\
.60\end{array}$ & & & $\begin{array}{r}.98 \\
1.51 \\
1.54 \\
1.52 \\
1.12\end{array}$ & $\begin{array}{l}1.36 \\
2.62 \\
2.03 \\
2.36 \\
2.80\end{array}$ & $\begin{array}{l}.72 \\
.58 \\
.76 \\
.64 \\
.40\end{array}$ \\
\hline $\begin{array}{l}\text { AF } \\
\text { CSI } \\
\text { DP }\end{array}$ & $\begin{array}{l}66 \\
39 \\
64\end{array}$ & $\begin{array}{l}5-5 \\
5-6 \\
5-7\end{array}$ & $\begin{array}{l}145 \\
120 \\
155\end{array}$ & $\begin{array}{r}10.10 \\
5.60 \\
4.00\end{array}$ & $\begin{array}{r}12 \\
14 \\
8\end{array}$ & $\begin{array}{l}1.90 \\
1.30\end{array}$ & $\begin{array}{l}4.40 \\
2.35 \\
7.15\end{array}$ & $\begin{array}{l}8.6 \\
4.9 \\
2.6\end{array}$ & \begin{tabular}{|l|}
.13 \\
.32 \\
.12
\end{tabular} & 2.3 & .33 & 1.7 & .40 & & & $\begin{array}{l}.46 \\
.36 \\
.28\end{array}$ & $\begin{array}{l}.53 \\
.28 \\
.88\end{array}$ & $\begin{array}{l}.77 \\
.93 \\
.31\end{array}$ & $\begin{array}{r}2.30 \\
2.40 \\
.55\end{array}$ & $\begin{array}{l}.32 \\
.31 \\
.56\end{array}$ \\
\hline $\begin{array}{r}\text { Mean } \\
\mathbf{s}\end{array}$ & $\begin{array}{l}53 \\
13\end{array}$ & $\begin{array}{r}5-4 \\
-2\end{array}$ & $\begin{array}{r}135 \\
17\end{array}$ & $\begin{array}{r}6.90 \\
.20\end{array}$ & $\begin{array}{r}12 \\
3\end{array}$ & $\begin{array}{r}2.00 \\
.50\end{array}$ & $\begin{array}{r}3.55 \\
.58\end{array}$ & Mea & $\mathrm{n}$ fo & 13 & .33. & & .22 & & 19 & & .26 & $\begin{array}{l}.93 \\
.41\end{array}$ & $\begin{array}{r}1.87 \\
.55\end{array}$ & $\begin{array}{l}.50 \\
.16\end{array}$ \\
\hline
\end{tabular}

Age in years.

Height in feet and inches.

Weight in pounds.

$\mathrm{MV}=$ Minute volume in liters (not corrected).

$\mathbf{N}=$ Number of respirations per minute.

VC $=$ Vital capacity in liters (not corrected).

FRA = Lung volume in liters as calculated by integration (not corrected).

case of a young Army physician, RCK. This trend follows through to the lung pathology subjects, in which group the sickest subjects had the least efficiency as well as the lowest effectiveness.

In all of these determinations the possibility exists that there is a portion of the lung so poorly ventilated that it does not show up at all within the sensitivity of the method. In general such volumes will be so small as to be negligible. However, it is much more likely that in the case of the bronchiectatic subjects a considerable portion of the lung volume might be so affected. This may have occurred in the cases of MMG and AS. So far as these tests are concerned, there seems to be no way out of this difficulty. Clinically this is not important since other ways are available for estimating the extent of lung pathology.

Some of the values for the lung volume (FRA) are unusually high. This is difficult to explain. High values can result from errors due to mask leaks or to leaks in other portions of the air manifold. Every effort was made to prevent such errors. An error in the starting time is easily detected by inspection of the tracing and may be cor- $k=$ Ventilation coefficient for individual component in turnovers per minute.

f $\quad=$ Decimal fraction of lung capacity associated with corresponding $\mathrm{k}$.

$\mathrm{K}=$ Effective coefficient of ventilation,

$\mathrm{E}=$ Efficiency of ventilation.

s $\quad=$ Standard deviation.

rected for. It seems possible that some of these do represent true values; because ventilation is poor, equilibrium is reached only slowly and these volumes do not show up in a short time by other methods.

\section{Modified breathing patterns}

Another important topic is the effect of variations in the breathing pattern on the effectiveness and efficiency of ventilation. It is well known that extremely rapid, shallow respiration is ineffective, and it is supposed that deep, slow respirations are the most effective, although it is easy to see that this can be carried to an extreme which becomes ineffective also. The question arises as to what, if any, is the optimal rate. This series does not show a correlation of either the efficiency or the effectiveness with rate, nor do the scatter diagrams indicate a maximum within the range represented. Quite a different question concerns the effects of changing the pattern for a given individual. The nitrogen elimination rate has been studied under two kinds of altered breathing pat- 
TABLE V

Lung ventilation data and characteristics for subjects with lung pathology at rest and with normal respiratory rate

\begin{tabular}{|c|c|c|c|c|c|c|c|c|c|c|c|c|c|c|c|c|c|c|c|c|}
\hline & & \multirow{2}{*}{ Age } & \multirow{2}{*}{ Ht } & \multirow{2}{*}{$\mathbf{W t}$} & & \multirow{2}{*}{$\mathbf{M V}$} & \multirow{2}{*}{$\mathbf{N}$} & \multirow{2}{*}{ VC } & \multirow{2}{*}{ FRA } & \multicolumn{2}{|c|}{$\mathbf{A}$} & \multicolumn{2}{|c|}{ B } & \multicolumn{2}{|c|}{ C } & \multicolumn{2}{|c|}{ D } & \multirow{2}{*}{$\mathbf{K}$} & \multirow{2}{*}{$\frac{\text { MV }}{\text { FRA }}$} & \multirow{2}{*}{$\mathbf{E}$} \\
\hline & & & & & & & & & & $\mathbf{k}$ & f & $\mathbf{k}$ & f & $\mathbf{k}$ & f & $\mathbf{k}$ & f & & & \\
\hline $\begin{array}{l}\text { EGA } \\
\text { EG } \\
\text { AS } \\
\text { MD } \\
\text { JD }\end{array}$ & $\begin{array}{l}\mathbf{M} \\
\mathbf{M} \\
\mathbf{F} \\
\mathbf{F} \\
\mathbf{M}\end{array}$ & $\begin{array}{l}71 \\
41 \\
57 \\
31 \\
75\end{array}$ & $\begin{array}{l}5-11 \\
6-1 \\
5-5 \\
5-2 \\
5-6\end{array}$ & $\begin{array}{r}142 \\
140 \\
124 \\
94 \\
132\end{array}$ & $\begin{array}{l}\text { Asthma } \\
\text { Emphysema } \\
\text { Bronchiectasis } \\
\text { Asthma, cystic } \\
\text { Emphysema }\end{array}$ & $\begin{array}{l}7.80 \\
9.50 \\
9.00 \\
7.00 \\
6.00\end{array}$ & $\begin{array}{r}16 \\
15 \\
11 \\
15 \\
4\end{array}$ & $\begin{array}{l}2.05 \\
2.50 \\
1.10 \\
2.00 \\
2.90\end{array}$ & $\begin{array}{l}3.35 \\
7.90 \\
2.50 \\
4.15 \\
6.00\end{array}$ & $\begin{array}{l}6.9 \\
6.9 \\
6.9 \\
4.6\end{array}$ & $\begin{array}{l}.18 \\
.14 \\
.42 \\
.11\end{array}$ & $\begin{array}{l}1.9 \\
1.2 \\
1.7\end{array}$ & $\begin{array}{l}.34 \\
.13 \\
.35\end{array}$ & .99 & .35 & $\begin{array}{l}.46 \\
.15 \\
.16 \\
.13 \\
.46\end{array}$ & $\begin{array}{l}.48 \\
.72 \\
.16 \\
.55 \\
.65\end{array}$ & $\begin{array}{l}.80 \\
.20 \\
.76 \\
.21 \\
.62\end{array}$ & $\begin{array}{l}2.3 \\
1.2 \\
3.6 \\
1.7 \\
1.0\end{array}$ & $\begin{array}{l}.35 \\
.17 \\
.21 \\
.12 \\
.62\end{array}$ \\
\hline $\begin{array}{l}\text { PES } \\
\text { RHT } \\
\text { RTE } \\
\text { GPF } \\
\text { MMG }\end{array}$ & $\begin{array}{l}\mathbf{F} \\
\mathbf{M} \\
\mathbf{M} \\
\mathbf{M} \\
\mathbf{F}\end{array}$ & $\begin{array}{l}65 \\
77 \\
50 \\
69 \\
65\end{array}$ & $\begin{array}{l}5-5 \\
5-10 \\
5-7 \\
6-1 \\
5-4\end{array}$ & $\begin{array}{l}139 \\
176 \\
150 \\
140 \\
135\end{array}$ & $\begin{array}{l}\text { Bronchiectasis } \\
\text { Emphysema } \\
\text { Asthma } \\
\text { Emphysema } \\
\text { Bronchiectasis }\end{array}$ & $\begin{array}{r}5.50 \\
7.00 \\
11.20 \\
12.70 \\
6.00\end{array}$ & $\begin{array}{l}16 \\
16 \\
19 \\
16 \\
14\end{array}$ & $\begin{array}{l}1.60 \\
3.10 \\
2.00 \\
3.30 \\
1.70\end{array}$ & $\begin{array}{l}4.50 \\
5.45 \\
4.25 \\
8.40 \\
2.60\end{array}$ & $\begin{array}{l}9.9 \\
3.0 \\
6.9 \\
7.7 \\
7.7\end{array}$ & $\begin{array}{l}.07 \\
.30 \\
.28 \\
.15 \\
.15\end{array}$ & $\begin{array}{l}1.7 \\
1.4 \\
1.1 \\
2.5\end{array}$ & $\begin{array}{l}.27 \\
.39 \\
.15 \\
.31\end{array}$ & $\begin{array}{l}.55 \\
.69\end{array}$ & .70 & $\begin{array}{l}.23 \\
.39 \\
.14\end{array}$ & $\begin{array}{l}.45 \\
.33 \\
.69\end{array}$ & $\begin{array}{l}.47 \\
.71 \\
.86 \\
.20 \\
1.09\end{array}$ & $\begin{array}{l}1.2 \\
1.3 \\
2.6 \\
1.5 \\
2.3\end{array}$ & $\begin{array}{l}.39 \\
.55 \\
.33 \\
.13 \\
.47\end{array}$ \\
\hline $\begin{array}{l}\text { MSG } \\
\text { EG }\end{array}$ & $\begin{array}{l}\mathbf{F} \\
\mathbf{M}\end{array}$ & $\begin{array}{l}39 \\
35\end{array}$ & $\begin{array}{l}5-3 \\
6-1\end{array}$ & $\begin{array}{l}142 \\
150\end{array}$ & $\begin{array}{l}\text { Fibrosis } \\
\text { Pneumoconiosis } \\
\text { (berylliosis) }\end{array}$ & $\begin{array}{r}8.00 \\
11.00\end{array}$ & $\begin{array}{l}16 \\
18\end{array}$ & $\begin{array}{l}3.00 \\
2.20\end{array}$ & $\begin{array}{l}3.55 \\
5.70\end{array}$ & $\begin{array}{l}4.9 \\
9.9\end{array}$ & $\begin{array}{l}.37 \\
.13\end{array}$ & 1.5 & .25 & .95 & .38 & $\begin{array}{l}.24 \\
.07\end{array}$ & $\begin{array}{l}.24 \\
.62\end{array}$ & $\begin{array}{l}.68 \\
.11\end{array}$ & $\begin{array}{l}2.2 \\
1.9\end{array}$ & $\begin{array}{l}.31 \\
.06\end{array}$ \\
\hline \multirow{2}{*}{\multicolumn{2}{|c|}{$\begin{array}{r}\text { Mean } \\
\text { s }\end{array}$}} & \multirow[t]{2}{*}{$\begin{array}{l}56 \\
17\end{array}$} & \multirow[t]{2}{*}{$\begin{array}{l}5-7 \\
0-4\end{array}$} & \multirow[t]{2}{*}{$\begin{array}{r}139 \\
15\end{array}$} & & \multirow[t]{2}{*}{$\begin{array}{l}8.40 \\
2.20\end{array}$} & $\begin{array}{r}15 \\
4\end{array}$ & $\begin{array}{r}2.30 \\
.60\end{array}$ & $\begin{array}{l}4.90 \\
1.70\end{array}$ & & & & & & & & & $\begin{array}{l}.56 \\
.30\end{array}$ & $\begin{array}{r}1.9 \\
.5\end{array}$ & $\begin{array}{l}.31 \\
.17\end{array}$ \\
\hline & & & & & & & \multicolumn{3}{|c|}{ Mean for 12} & & .24 & & .18 & & .10 & & .48 & & & \\
\hline
\end{tabular}

M $=$ Male.

$\mathrm{F}$ = Female.

Age in years.

Height in feet and inches.

Weight in pounds.

$\mathrm{MV}=$ Minute volume in liters (not corrected).

$\mathrm{N}=$ Number of respirations per minute.

VC = Vital capacity in liters (not corrected).

FRA = Lung volume in liters as calculated by integration (not corrected).

terns, forced hyperventilation, and the hyperpnea accompanying exercise.

\section{Hyperventilation}

The subjects were instructed to breathe as deeply and as rapidly as possible during the hyperventilation period. Various intervals during denitrogenation were used as hyperventilating periods. Many subjects who attempted this hardly changed their minute volume, but some reached minute volumes exceeding 30 liters $/ \mathrm{min}$.

In one set of experiments the subjects hyperventilated for one minute after denitrogenation had been under way for five minutes or more with normal respiration. In these cases the concentration of nitrogen in the expired air fell during the first two or three respiratory cycles to a minimum which persisted until normal respiration was resumed, after which the concentration rose during the next three or four respirations to meet and then follow what evidently would have been the curve had there been no hyperventilating period. k = Ventilation coefficient for individual component in turnovers per minute.

f $=$ Decimal fraction of lung capacity associated with corresponding $\mathbf{k}$.

$\mathrm{K}$ = Effective coefficient of ventilation.

$\mathrm{E}=$ Efficiency of ventilation.

$\mathrm{s} \quad=$ Standard deviation.

In general the rate of nitrogen elimination while the concentration was at its minimum was the same as the average for the adjacent normal periods, within the errors of measurement. During the first few hyperventilating respirations the rate was higher than the normal rate for that period, but during the first few normal respirations which succeeded the hyperventilation the rate was lower than normal, so there was very little, if any, net gain in the overall rate of nitrogen elimination. A partial interpretation of this is that during this period most of the nitrogen comes from the tissues and except in so far as the cardiac output is increased, no great change in the nitrogen elimination rate could be produced.

Other experiments involved hyperventilation at the beginning of denitrogenation for a few cycles or for a minute or longer. When the hyperventilation involved only a few quick deep breaths, the concentration did fall rapidly, reaching values of about $5 \%$ in the first 20 seconds. But when normal respiration was resumed the concentration 


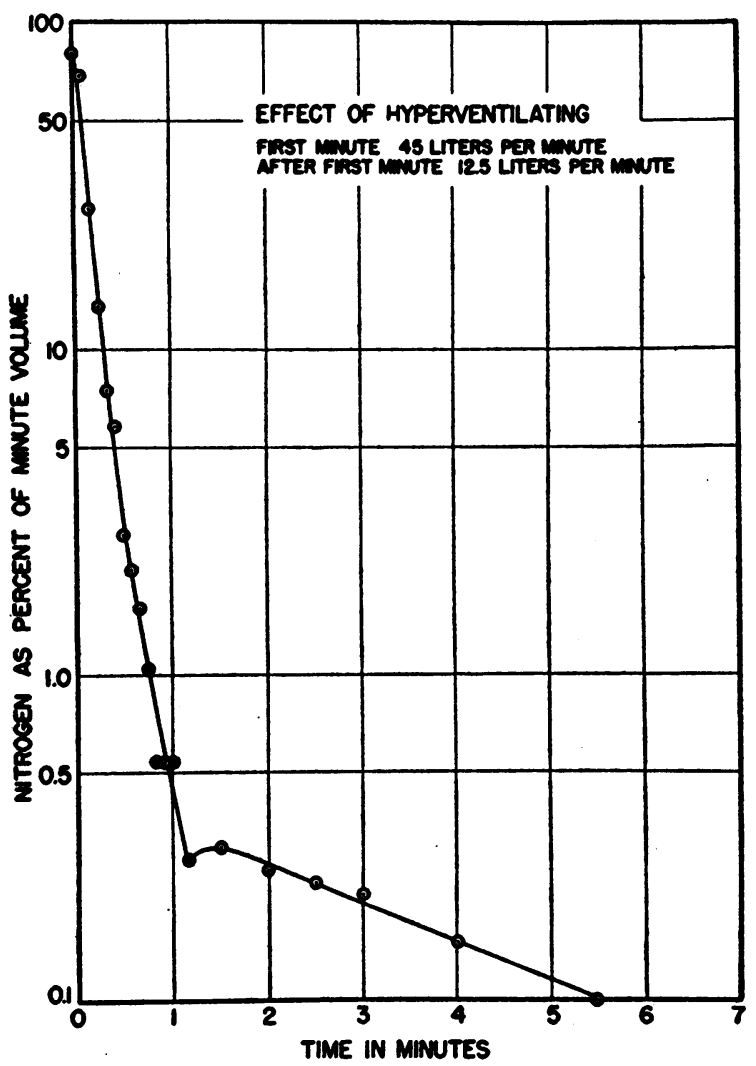

Fig. 8. Rate of Elimination of Nitrogen From Lungs and Tissues as Obtained Experimentally with Subject Hyperventilating for First Minute, then Resuming, in so far as Possible, Normal Respiration

again rose in a few respirations nearly to meet the predicted normal curve for that individual and then fell only slightly if at all below the normal curve. The total nitrogen eliminated during hyperventilation was frequently considerably less than had been anticipated, being less than $25 \%$ greater than normal for a minute volume in excess of twice normal. It was only with prolonged periods of hyperventilation that it was found possible to clear the lungs of their original nitrogen and to obtain what appeared to be a pure tissue curve upon the resumption of normal respiration. Figure 8 shows such a curve which was obtained on one of the normal subjects (AHS) when he hyperventilated at the rate of $45 \mathrm{liters} / \mathrm{min}$. for the first minute, then resumed normal respiration at 12.5 liters/min. An analysis of this subject's resting curve without hyperventilation is given in Table II. In that experiment his normal minute volume was 10.2 liters/min., his lung volume was calculated as 2.45 liters, and the derived values were $\mathrm{K} 1.45, \mathrm{MV} / \mathrm{FRA} 2.13$, and $\mathrm{E} 0.68$. The analysis of his hyperventilating curve gives a lung volume of 3.78 liters of which 2.20 liters is associated with a $\mathrm{k}$ of 11.5 , and 1.58 liters with a $\mathrm{k}$ of 4.9. The derived values are $\mathrm{K} 7.3, \mathrm{MV} / \mathrm{FRA}$ 8.6, and $\mathrm{E} 0.85$. In general, when the minute volume was not increased so greatly, the efficiency was not improved, but was lowered. Evidently those portions of the lung which are well ventilated become better ventilated, but the poorly ventilated portions are not changed greatly. In a case like this, more of the lung is brought to the same or nearly the same turnover rate and the efficiency is improved accordingly.

\section{Exercise}

A set of experiments involving exercise was conducted during the early phases of this work on the theory that under such conditions it would be possible to wash the nitrogen out of the lungs sufficiently rapidly to use the tissue nitrogen elimination curve as a measure of the cardiac output. This did not prove to be feasible, and the curves obtained have been re-examined to see what they show about the lung phase of the process. The subjects used in these experiments were studentathletes, young males out for track and basketball. The exercise involved pedalling a stationary bicycle equipped with a magnetic brake so that the exercise could be graded. The amount of work done was not determined, but the oxygen consumption was usually in the range of 800 to 1,200 cc. of oxygen per minute during the exercise. A four-minute warm-up period with the subject breathing atmospheric air preceded the nitrogen elimination. Unfortunately resting curves were obtained on only a few of these subjects.

One subject (ES) who has mild asthma showed the following results in a comparison of resting and exercise denitrogenation (Table VI). The exercise was adjusted to be quite strenuous. His oxygen consumption during exercise was $2,100 \mathrm{cc}$. of oxygen per minute.

By increasing his minute volume more than four times this subject increased the effectiveness of ventilation only by a factor of 2 . On the other hand his lung volume was increased by a factor of 1.8 , so the real loss in efficiency was not great.

The results indicate that in the case of the 
TABLE VI

Comparison of resting and exercising denitrogenation

\begin{tabular}{l|c|c|c|c|c|c|c|c|c|c|c|c}
\hline & $\mathrm{MV}$ & $\mathrm{LV}$ & $\mathrm{k}$ & $\mathrm{f}$ & $\mathrm{k}$ & $\mathrm{f}$ & $\mathrm{k}$ & $\mathrm{f}$ & $\mathrm{K}$ & $\mathrm{MV} / \mathrm{LV}$ & $\mathrm{E}$ \\
\hline Resting & $\mathbf{5 . 3 0}$ & 2.86 & 2.88 & .60 & .32 & .40 & - & - & .68 & 1.86 & .36 \\
Exercising & 24.20 & $\mathbf{5 . 0 5}$ & $\mathbf{5 . 7 5}$ & .79 & .92 & .13 & .15 & .08 & 1.25 & 4.65 & .27 \\
\hline
\end{tabular}

athletes a similar phenomenon occurs. The elimination of lung nitrogen is not complete at the end of one minute and frequently not at the end of two minutes. As was the case in forced hyperventilation, it appears that less gain of effectiveness of ventilation is achieved than would be predicted from the change in the minute volume because some portions of the lung remain poorly ventilated.

\section{SUMMARY}

A theory expressing the ventilation of the lung in terms of turnover rates is developed, with Jones's theory of tissue denitrogenation being combined with the lung theory. Variations by a factor of 3 are found in the effectiveness and the efficiency of the ventilation of the lungs in normal resting subjects. The effectiveness of ventilation is correlated with age. No significant difference is found between the ventilatory characteristics of polycythemic subjects and normal ones; if there is an anoxic factor in polycythemia vera it is not due to defective lung ventilation. The use of the measures of effectiveness and efficiency as criteria for the estimation of physical fitness and the significance of lung pathology is suggested. Hyperventilation produces less increase in the effectiveness of lung ventilation than is expected. It is very difficult to produce changes in the ventilation of the deeper pulmonary structures.

\section{ACKNOWLEDGMENT}

The authors are greatly indebted to Dr. John H. Lawrence for his continuous interest and encouragement of this work.

\section{BIBLIOGRAPHY}

1a. Darling, R. C., Cournand, A., Mansfield, J. S., and Richards, D. W., Jr., Studies on the intrapulmonary mixture of gases. I. Nitrogen elimination from blood and body tissues during high oxygen breathing. J. Clin. Invest., 1940, 19, 591. b. Cournand, A., Darling, R. C., Mansfield, J. S., and Richards, D. W., Jr., Idem. II. Analysis of the rebreathing method (closed circuit) for measuring residual air. Ibid., 1940, 19, 599.

c. Darling, R. C., Cournand, A., and Richards, D. W., Jr., Idem. III. An open circuit method for measuring residual air. Ibid., 1940, 19, 609.

2. Cournand, A., Baldwin, E. DeF., Darling, R. C., and Richards, D. W., Jr., Idem. IV. Significance of pulmonary emptying rate and simplified open circuit measurement of residual air. Ibid., 1941, 20, 681.

3. Darling, R. C., Cournand, A., and Richards, D. W., Jr., Idem. V. Forms of inadequate ventilation in normal and emphysematous lungs analyzed by means of breathing pure oxygen. Ibid., 1944, 23, 55.

4. Meneely, G. R., and Kaltreider, N. L., The volume of the lung determined by helium dilution. Description of the method and comparison with other procedures. Ibid. 1949, 28, 129.

5. Birath, G., Lung volume and ventilation efficiency. Act. med. Scandinav., 1944, Suppl. 154.

6. Bateman, J. B., Measurement of intrapulmonary mixing and pulmonary midcapacity "functional residual air." Proc. Staff Meetings Mayo Clinic, 1946, 21, 112.

7. Bateman, J. B., Boothby, W. M., and Helmholz, H. F., Jr., Studies of lung volumes and intrapulmonary mixing: notes on open-circuit methods including use of a new pivoted type gasometer for lung clearance studies. J. Clin. Invest., 1949, 28, 679.

8. Boothby, W. M., Lundin, G., and Helmholz, H. F., Jr., A gaseous nitrogen elimination test to determine pulmonary efficiency. Proc. Soc. Exper. Biol. \& Med., 1948, 67, 558.

9. Forssander, C. A., and White, C., Mixing of alveolar air with dead space air during expiration. J. Applied Physiol., 1949, 2, 110.

10. Riley, R. L., and Cournand, A., "Ideal" alveolar air and the analysis of ventilation-perfusion relationships in the lungs. Ibid., 1949, 1, 825.

11. Rahn, H., Inhomogeneity of alveolar air. Am. J. Physiol., 1948, 155, 462.

12. Rahn, H., A concept of mean alveolar air and the ventilation-blood flow relationships during pulmonary gas exchange. Am. J. Physiol., 1949, 158, 21.

13. Siri, W., A mass spectroscope for analysis in the low mass range. Rev. Scient. Instruments, 1947, 18, 540. 
14. Jones, H. B., Preoxygenation and nitrogen elimination. U. S. Air Force Aero Medical Laboratory report MCREXD-696-114, 3 March 1948.

15. Jones, H. B., Nitrogen elimination, in: Glasser, O., Medical Physics. Year Book Publishers, Inc., Chicago, 1950, 2nd ed.

16a. Smith, R. E., and Morales, M. F., On the theory of blood-tissue exchanges. I. Fundamental equations. II. Applications. Bull. Math. Biophys., 1944, 6, $125 ; 133$.

b. Morales, M. F., and Smith, R. E., Idem. III. Circulation and inert-gas exchanges at the lung, with special reference to saturation. Ibid., 141.
17. Krogh, M., Diffusion of gases through the lungs of man. J. Physiol., 1915, 49, 271.

18. Roughton, F. J. W., Average time spent by the blood in the human lung capillary and its relation to the rates of carbon monoxide uptake and elimination in man. Am. J. Physiol., 1945, 143, 621.

19. Harrop, G. A., Jr., and Heath, E. H., Pulmonary gas diffusion in polycythemia vera. J. Clin. Invest., 1927, 4, 53.

20. Roth, L. W., Whitehead, R. W., and Draper, W. B., Studies on diffusion respiration. II. Survival of the dog following a prolonged period of respiratory arrest. Anesthesiology, 1947, 8, 294. 